Article

\title{
Scientific Performance and Mapping of the Term STEM in Education on the Web of Science
}

\author{
Francisco-Javier Hinojo-Lucena ${ }^{1}$, Pablo Dúo-Terrón ${ }^{2}$, Magdalena Ramos Navas-Parejo ${ }^{1, *}$ \\ Carmen Rodríguez-Jiménez ${ }^{1}$ and Antonio-José Moreno-Guerrero ${ }^{1}$ (i) \\ 1 Department of Didactics and School Organization, University of Granada, Granada 18071, Spain; \\ fhinojo@ugr.es (F.-J.H.-L.); carmenrj@ugr.es (C.R.-J.); ajmoreno@ugr.es (A.-J.M.-G.) \\ 2 CEIP Principe Felipe, Ministry of Education and Vocational Training, Ceuta 51003, Spain; \\ pabloduo@ceipprincipefelipe.es \\ * Correspondence: magdalena@ugr.es
}

Received: 13 February 2020; Accepted: 11 March 2020; Published: 14 March 2020

check for updates

\begin{abstract}
Technological progress is causing terms such as "STEM", an acronym for Science, Technology, Engineering and Mathematics, to burst into the educational arena, marking a new era in the application of innovative and motivating teaching and learning processes. The objective of this research is to analyze the trajectory and the transcendence of the "STEM" concept in the educational field, having as reference the reported literature of Web of Science. The methodology applied in this research is based on bibliometrics, analyzing both the performance and the structural and dynamic development of the concept through a co-word analysis. The total number of documents analyzed is 4390. The results show that the scientific community mainly uses English and research papers to present their results. From 2015 onwards, the main lines of research are beginning to be established, which focus on "women" and "science". It can be concluded that the term "STEM" in education is beginning to have a greater incidence and impact on the processes of teaching and learning, especially in the field of science, although there are currently discrepancies between men and women in its use.
\end{abstract}

Keywords: STEM; education; bibliometric analysis; co-words; scientific mapping; Web of Science

\section{Introduction}

The characteristics of today's society have meant that the use of information and communication technologies (ICT) has become a common practice in everyday life [1]. The technological impact has generated important changes, both in the way of interacting with the environment and in people's behaviour [2]. In the educational field, the inclusion of ICTs in society has had a full influence on teaching and learning processes [3], encouraging teachers to benefit increasingly from their potential [4], reported from the perspective of teachers and students themselves [5]. Specifically, educational technology promotes improved motivation, access to a variety of educational resources [6], as well as a greater attitude among students [7] who value and welcome active methodologies with an innovative character [8]. In this sense, it can be determined that ICTs have gone from being a simple support tool in learning spaces [9] to becoming an inseparable part of today's pedagogical processes [10], generating the appearance of new training environments [11] and new learning experiences [12].

Among the new pedagogical actions, we find the term STEM, an acronym for the terms Science, Technology, Engineering and Mathematics. This term has had an increasing impact in the educational field, especially in recent years. It is defined as an interdisciplinary pedagogical application of the disciplines of Science, Technology, Engineering and Mathematics, through the integration of all curricular elements [13-17], being used at various educational stages, by integrating content in a 
practical way, from a holistic and meaningful approach, with the intention of being applied in a practical way in one's own society [18-20].

The term of STEM education has its beginnings from a non-educational perspective. It is in recent times, where due to social and economic reasons, the term STEM has been introduced in the educational field. For this reason, the term of STEM education should be taken with caution, since for some authors it is represented as a pedagogical action that prepares students for university engineering courses; others value it as a career path for an engineering profession, while others value it as a component of general education, when trying to improve STEM knowledge in the population [21]. The use of STEM in education involves students working as a team, to focus on problem solving, to increase decision making and creativity, to improve critical thinking and self-esteem, to acquire significant learning, to develop interaction between peers, to enhance self-efficacy, scientific identity and an attitude towards mathematics and science, to develop active learning, to improve reasoning skills, collaboration and the self-regulation of learning [22-38].

The processes of teaching and learning through the STEM teaching method require an adequate development of teaching professionals [39-41], where years of experience, level of education and subject matter expertise have a direct influence on whether the teaching method is applied with assurance, as well as increased involvement of families who support STEM learning at home [42,43].

The methodological approach on teaching STEM has recently evolved in education from using traditional media to more advanced technological media [44,45]. Moreover, more and more studies are associated with other teaching methods considered innovative, such as online learning, gamification, learning communities, design-based science education or augmented reality [46-51]. This methodology brings to the educational field another active teaching method, which allows to develop the competences of the students towards the society [28].

One of the main problems associated with the STEM teaching method is the existing gender gap in certain countries in South America, Central America and Europe, as reflected in the studies of [52], due to the greater use of this pedagogical technique by men than by women [53-55]. This has generated the emergence of new projects such as W-STEM to reduce this gap [56,57]. In addition, there are other factors, such as socioeconomic and cultural level, that affect the development of educational practices with STEM, where students with low socioeconomic and cultural levels have less possibilities to develop this teaching method [58-60].

\section{Justification and Research Objectives}

This research tries to analyze the term "STEM" in the educational field, from the scientific literature collected in the Web of Science (WoS), following a methodological procedure based on scientific mapping; that is, graphic representation of science through the use of information of a relational nature, taking into account various bibliometric indicators, such as h-index, g-index, hg-index and q2-index; the performance of the scientific production, being considered as the analysis of production, activity, quality and impact measures; and the structural development of the generated terms, with the intention of knowing the trajectory and the importance of this topic in the scientific community. The reason for using bibliometrics is to try to analyze, at a statistical and sociometric level, the scientific literature, through the use of mathematical models, analyzing the size, growth and distribution of the scientific literature in the study of the structure and social dynamics of the selected subject of study, in this case being the term of STEM in education [61]. In addition, to find out if sustainability is present in STEM studies in the educational field, after the analysis of the generated database, no bibliometric studies have been found on the use of STEM in the field of education. Therefore, this study tries to guide the scientific community that wants to study and develop their research on the term "STEM" in the educational field. The objectives established in this research are:

- Determining the scientific performance and production of literature concerning "STEM" in the educational field (year of publication, language, type of documents, organizations, authors, sources of origin, countries and citation). 
- Specifying the scientific evolution of this term according to the key words in the different scientific documents.

- Delimiting the most influential topics in the conceptual association, obtained from the analysis of the key words established by the authors in the different documents.

\section{Materials and Methods}

\subsection{Research Design}

The research method developed in this study is based on bibliometrics [62], coming from the branch of scientometrics [63], to quantify, analyze and identify the quality, productivity and scientific evolution of a certain subject of study [64], being in this case, "STEM". To this end, firstly, analytical tracking and documentary quantification techniques have been used to evaluate research performance in the field of study [65] specified in the section on Procedure and Data Analysis. Secondly, scientific mapping has been carried out [66] to find out the particular and general themes of the research, as well as their thematic evolution [67]. This scientific mapping takes as main references, the $h$ index and the number of citations [68], and as secondary indicators, the g, hg and q2 indexes [69], trying to offer as much information as possible about the metrics of the field of study [70]. Throughout this procedure, a PRISMA protocol has been applied to collect scientific output [71], and various criteria for inclusion in the control variables to show the results obtained [72].

\subsection{Procedure and Data Analysis}

The study has followed several phases. Firstly, the database for the bibliometric study was determined, in this case, the Web of Science (WoS) (https://bit.ly/2TujHlw), by Thomson Reuters, in its main collection (Science Citation Index, Social Science Citation Index, Art \& Humanities Citation Index, Conference Proceedings Citation Index Sciences / Social Science \& Humanities and Emerging Sources Citation Index), given that it is a repository, within the branch of social sciences that houses a large number of high-impact scientific productions. Then, the keyword was selected to develop the search in WoS. In this case, bearing in mind those indicated in the special issue of Sustainability, called "Integration of ICT in STEM Education", the term "STEM" was used in the subject in the category "Education Educational Research", locating the word established in the title, or the abstract and or the key words of the various scientific texts. The total number of documents collected in the first place was 4458. Later, through the application of the PRISMA protocol (Figure 1), with the intention of providing a more detailed explanation of the various steps and processes followed, in order to select the documents used in this research, the inclusion and exclusion criteria are specified in this protocol. The final number of documents was 4390 . The search for documentation began in January 2020, locating the texts from 2010 to 2019, inclusive.

A number of inclusion criteria have been established to analyze the performance of scientific production. The intention is to present the most relevant data related to year of publication, language, type of documents, organizations, authors, sources of origin, countries and citation (Table 1).

Table 1. Production indicators and inclusion criteria.

\begin{tabular}{cc}
\hline Indicators & Criteria \\
\hline Year of publication & $2010-2019$ \\
\hline Language & $x \geq 6$ \\
\hline Type of documents & $x \geq 100$ \\
\hline Organizations & $x \geq 100$ \\
\hline Authors & $x \geq 12$ \\
\hline Sources of origin & $x \geq 100$ \\
\hline Countries & $x \geq 100$ \\
\hline Citation & The four most cited documents \\
\hline
\end{tabular}




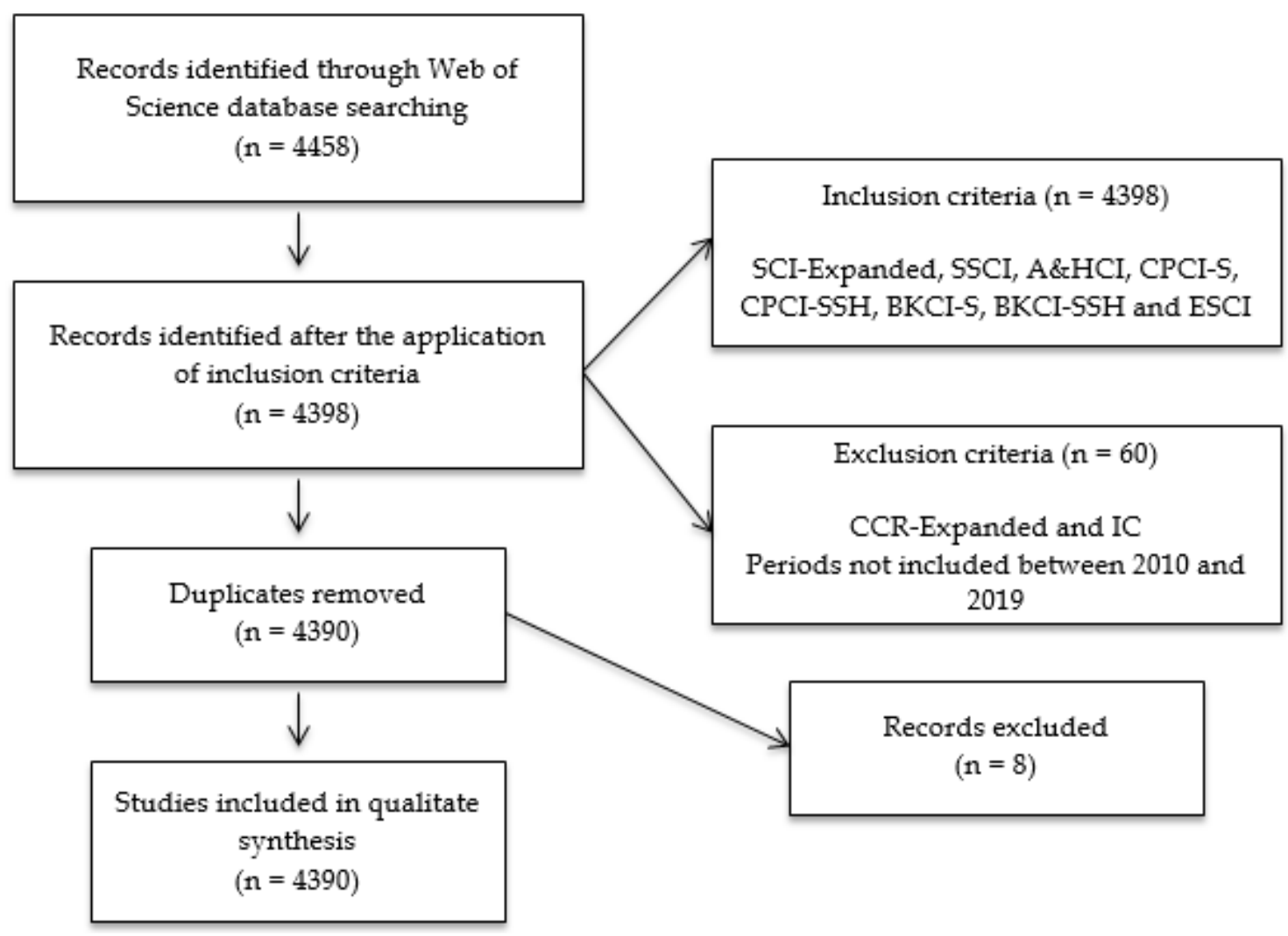

Figure 1. Flowchart according to the PRISMA Declaration.

The structural and dynamic development, from a longitudinal axis, has been carried out with the SciMAT tool [73] (Figure 2), following the steps marked by the experts in the use of it [74]:

- Detection: In this phase, we proceed to the analysis of the keywords of all the scientific production $(\mathrm{n}=9146)$ and create a map of co-occurrence through nodes, thus generating a standardized network of co-words. In this way, the most relevant keywords $(n=8333)$ are obtained, which, by means of a clustering algorithm, the topics are configured, as well as the connection established between them.

- Representation: The creation of strategic diagrams and thematic networks continues, under the principles of centrality and density. The graphic representation is structured in four sectors: (1) Top-right $=$ motor and relevant themes; (2) Top-left $=$ consolidated but isolated themes; (3) Bottom-left $=$ developing or disappearing themes; and (4) Bottom-right $=$ cross-cutting themes and with little development.

- Location: The configuration of the time intervals continues. Try to collect the documents by time periods. In this case, ten intervals have been created (I1 $=2010$; I2 $=2011 ; \mathrm{I} 3=2012$; I $=2013$; $\mathrm{I} 5=2014 ; \mathrm{I} 6=2015 ; \mathrm{I} 7=2016 ; \mathrm{I} 8=2017 ; \mathrm{I} 9=2018 ; \mathrm{I} 10=2019)$, following the criteria of document equity in all established periods.

- Performance analysis: Finally we proceed with the analysis of the data, obtaining the connections given between the key words or themes. For this purpose, the unit of analysis specified by the assessment unit was determined, in this case, the keywords set by the authors in the documents and the keywords set by WoS. The frequency threshold sets the minimum frequency of the intervals. The network type elaborates a multiple connection of co-occurrence of keywords and authors. The value of coincidence binding articulates the established intervals. The normalization measure determines the binding threshold, revealing the minimum connection of the occurrence. The normalization of connections is based on the equivalence index eij $=$ cij2/Root $(\mathrm{ci}-\mathrm{cj})$. The clustering algorithm, by means of simple centers, makes the map of subjects and related 
subnetworks. The evolutionary measure, through the Jaccard Index, shows the similarity measure that elaborates the evolutionary map and the transition map through the inclusion rate. All this is collected, with its corresponding indicators in Table 2.

Table 2. Production indicators and inclusion criteria.

\begin{tabular}{|c|c|}
\hline Configuration & Values \\
\hline Analysis unit & Keywords authors, keywords WoS \\
\hline \multirow[t]{2}{*}{ Frequency threshold } & $\begin{array}{c}\text { Keywords: } \mathrm{I}_{1}=(2), \mathrm{I}_{2}=(2), \mathrm{I}_{3}=(3), \mathrm{I}_{4}=(3), \mathrm{I}_{5}=(4), \\
\mathrm{I}_{6}=(4), \mathrm{I}_{7}=(5), \mathrm{I}_{8}=(6), \mathrm{I}_{9}=(5), \mathrm{I}_{10}=(5)\end{array}$ \\
\hline & Authors: $\mathrm{PX}=(2)$ \\
\hline Network type & Co-occurrence \\
\hline \multirow[t]{2}{*}{ Co-occurrence union value threshold } & $\begin{array}{c}\text { Keywords: } \mathrm{I}_{1}=(1), \mathrm{I}_{2}=(1), \mathrm{I}_{3}=(1), \mathrm{I}_{4}=(1), \mathrm{I}_{5}=(1), \\
\mathrm{I}_{6}=(1), \mathrm{I}_{7}=(2), \mathrm{I}_{8}=(2), \mathrm{I}_{9}=(2), \mathrm{I}_{10}=(2)\end{array}$ \\
\hline & Authors: $\mathrm{PX}=(2)$ \\
\hline Normalization measure & Equivalence index \\
\hline Clustering algorithm & Maximum size: 9; Minimum size: 3 \\
\hline Evolutionary measure & Jaccard index \\
\hline Overlapping measure & Inclusion Rate \\
\hline
\end{tabular}

Note: $\mathrm{I}_{1}=(2010), \mathrm{I}_{2}=(2011), \mathrm{I}_{3}=(2012), \mathrm{I}_{4}=(2013), \mathrm{I}_{5}=(2014), \mathrm{I}_{6}=(2015), \mathrm{I}_{7}=(2016), \mathrm{I}_{8}=(2017), \mathrm{I}_{9}=(2018)$, $\mathrm{I}_{10}=(2019)$.
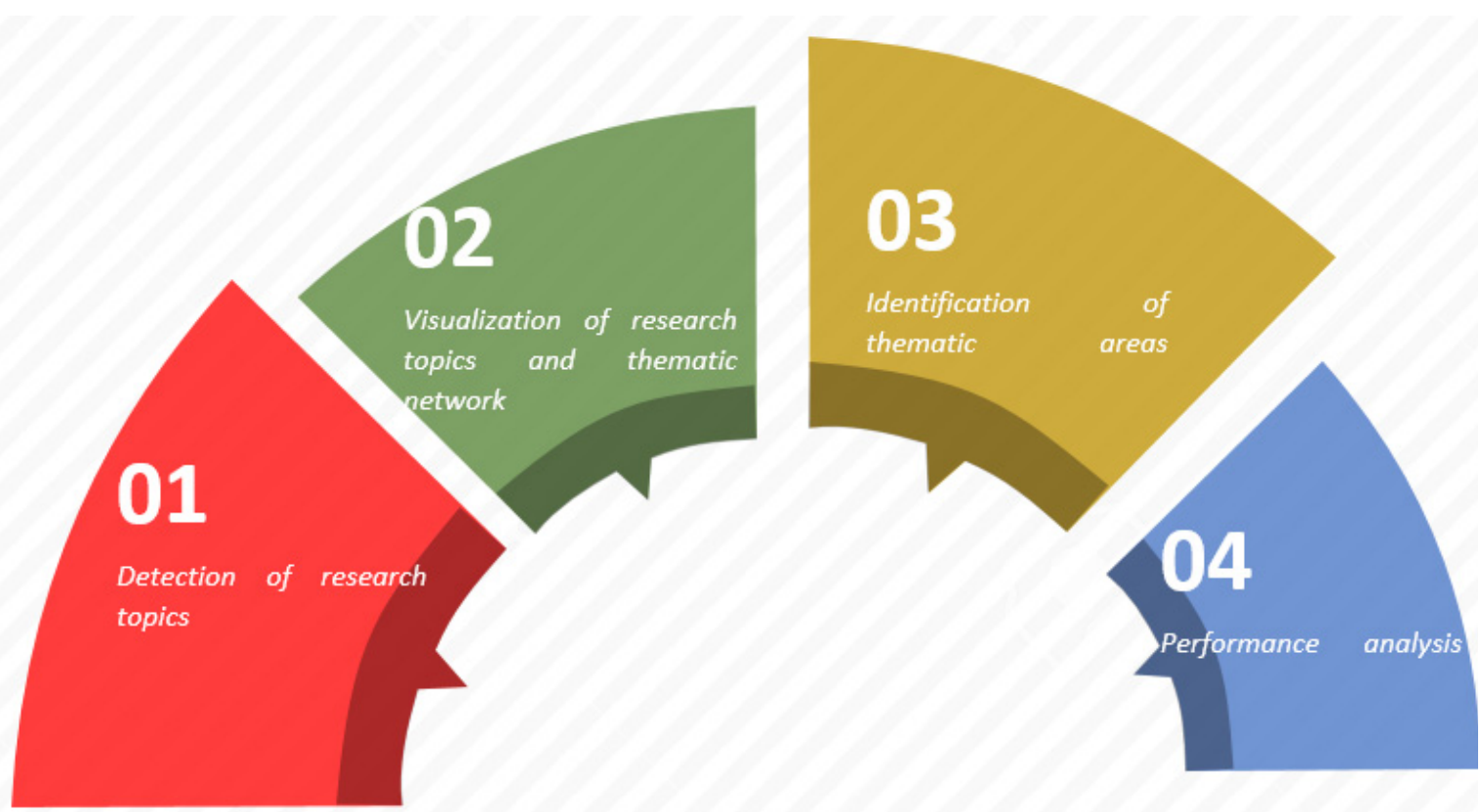

Figure 2. Phases of longitudinal co-word analysis using SciMAT.

\section{Results}

\subsection{Performance and Scientific Production}

The temporal evolution of the 4390 scientific texts analyzed in the years between 2010 and 2019, offers an ascending evolution from 2010 onwards, although this evolution is not constant, given that there are small decreases in production in the years 2012, 2015 and 2018. The year in which the highest production was recorded is 2017 (Figure 3). 


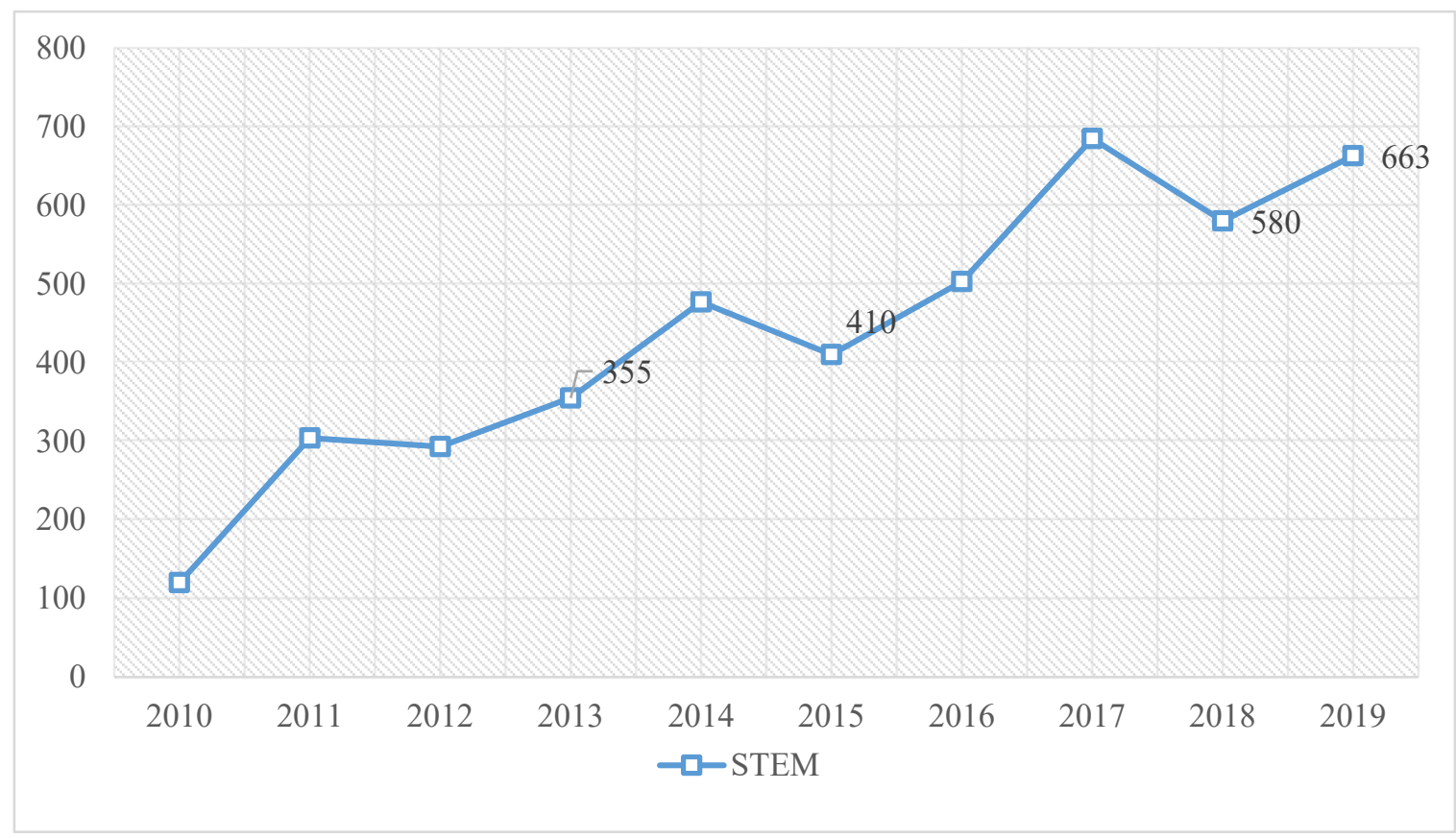

Figure 3. Evolution of scientific production of diet in education in the Web of Science (WoS). (Table 3).

The language primarily used by the educational community to present their results is English

Table 3. Scientific language used in EDIE.

\begin{tabular}{cc}
\hline Language & $\mathbf{n}$ \\
\hline English & 4317 \\
\hline Spanish & 32 \\
\hline Turkish & 11 \\
\hline Portuguese & 6 \\
\hline
\end{tabular}

The type of documents used are articles and the number of communications is relevant, since it is another means used to show the scientific evidence (Table 4).

Table 4. Document types.

\begin{tabular}{cc}
\hline Document Types & n \\
\hline Article & 2736 \\
\hline Proceedings paper & 1395 \\
\hline Book Chapter & 448 \\
\hline Editorial Material & 147 \\
\hline Early Access & 103 \\
\hline
\end{tabular}

At the institutional level, Purdue University is the institution of reference for this type of study, followed by the University of North Carolina (Table 5). 
Table 5. Institution.

\begin{tabular}{cc}
\hline Institution & $\mathbf{n}$ \\
\hline Purdue University & 144 \\
\hline University of North Carolina & 127 \\
\hline State University System of Florida & 104 \\
\hline University of California System & 104 \\
\hline University of Texas System & 103 \\
\hline
\end{tabular}

The most prolific authors on the subject are T.J. Moore and C.C. Johnson. The rest of the authors following, have, in this case, a great diversity of scientists working on the same field of knowledge (Table 6).

Table 6. Authors.

\begin{tabular}{cc}
\hline Authors & n \\
\hline Moore, T.J. & 25 \\
\hline Johnson, C.C. & 22 \\
\hline Grandgenett, N. & 19 \\
\hline Nugent, G. & 16 \\
\hline Barlex, D. & 15 \\
\hline Henderson, C. & 15 \\
\hline Osman, K. & 14 \\
\hline Banks, F. & 14 \\
\hline Capraro, R.M. & 14 \\
\hline Osman, K. & 13 \\
\hline Guzey, S.S. & 13 \\
\hline Roehrig, G.H. & 13 \\
\hline
\end{tabular}

The main sources of exposure of scientific work are the documents generated from the conferences. The first journal that deals with this topic is the Journal of Science Education and Technology (Table 7).

Table 7. Source titles.

\begin{tabular}{cc}
\hline Source titles & $\mathbf{n}$ \\
\hline ASEE Annual Conference Exposition & 606 \\
\hline 2014 ASEE Annual Conference & 168 \\
\hline 2011 ASEE Annual Conference Exposition & 151 \\
\hline 2012 ASEE Annual Conference & 136 \\
\hline INTED Proceedings & 122 \\
\hline Edulearn Proceedings & 117 \\
\hline Journal of Science Education and Technology & 117 \\
\hline International Journal of STEM Education & 106 \\
\hline
\end{tabular}

The country with the highest production is the United States, but it is closely followed by England and Australia, which shows the international character of the subject (Table 8). 
Table 8. Countries.

\begin{tabular}{cc}
\hline Country & $\mathbf{n}$ \\
\hline United States & 247 \\
\hline England & 226 \\
\hline Australia & 195 \\
\hline Spain & 128 \\
\hline Canada & 124 \\
\hline Germany & 103 \\
\hline
\end{tabular}

Grover and Pea (2013) are the scientific community's reference publications for developing studies on "STEM" in the educational field, with a total of 326 citations (Table 9).

Table 9. Most cited articles.

\begin{tabular}{cc}
\hline Reference & Citations \\
\hline$[75]$ & 326 \\
\hline$[76]$ & 241 \\
\hline$[77]$ & 226 \\
\hline$[78]$ & 192 \\
\hline
\end{tabular}

\subsection{Structural and Thematic Development}

The keyword continuity between intervals shows information about outgoing, incoming and matching keywords in the set periods. The ascending arrow indicates the keywords leaving the period. The down arrow indicates the keywords entered in the period. The horizontal arrow provides keyword matching between periods. In this case, bearing in mind the information shown in Figure 4, it can be seen that there is a before and after in the year 2015, given that before that date, the coincidence between most of the periods was less than $30 \%$, which marks a settlement of the subject matter by the scientific community. On the other hand, from 2015 onwards, the coincidence of key words between the periods studied shows a settlement and delimitation of the field of study, given that the level of coincidence between periods is higher than $30 \%$ in all cases.

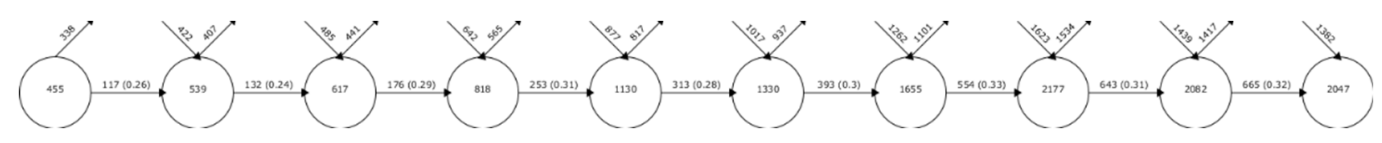

Figure 4. Continuity of keywords between contiguous intervals.

The academic performance of the different topics generated by SciMAT is shown below. These themes are represented by the periods established above. This shows the topics with various bibliometric indicators, presenting in this case the $\mathrm{h}$ index [79], $\mathrm{g}$ index [80], hg index [81] and $\mathrm{q}^{2}$ index [82], thus offering information on the most relevant topics in each of the intervals marked. According to the data revealed in Table 10, there has not been a theme that, due to its bibliometric indicators, is a reference year after year, except in the years 2017 and 2018, where "science" presents the highest bibliometric values. In the remaining years, there has been an evolution in the field of research, with "knowledge" in 2010 being the largest bibliometric indicator; "students and women" in 2011; "science" in 2012; "choice" in 2013; "mathematics" in 2014; "instructions" in 2015; "achievement" and "women" in 2016; and "women", "gender differences", "mathematics", "STEM education" and "motivation" in 2019. As can be seen, the main research has been oriented towards "women" and "science". 
Table 10. Thematic performance.

\begin{tabular}{|c|c|c|c|c|c|c|}
\hline \multicolumn{7}{|c|}{ Interval 2010} \\
\hline Denomination & Works & Index-h & Index-g & Index-hg & Index- $\mathrm{q}^{2}$ & Citations \\
\hline Stem-Cell-Research & 3 & 3 & 3 & 3 & 4.58 & 27 \\
\hline Knowledge & 5 & 5 & 5 & 5 & 10.49 & 99 \\
\hline Women & 4 & 4 & 4 & 4 & 20.3 & 329 \\
\hline Beliefs & 5 & 3 & 4 & 3.46 & 10.25 & 158 \\
\hline Persistence & 5 & 3 & 3 & 3 & 7.35 & 60 \\
\hline STEM & 9 & 2 & 2 & 2 & 11.58 & 79 \\
\hline Students & 5 & 2 & 4 & 2.83 & 7.75 & 36 \\
\hline Completion-rate & 2 & 2 & 2 & 2 & 3.46 & 12 \\
\hline \multicolumn{7}{|c|}{ Interval 2011} \\
\hline Denomination & Works & Index-h & Index-g & Index-hg & Index- $\mathrm{q}^{2}$ & Citations \\
\hline Faculty & 4 & 3 & 3 & 3 & 11.49 & 155 \\
\hline Career-Development & 3 & 1 & 1 & 1 & 8.37 & 70 \\
\hline Teacher-change & 3 & 1 & 1 & 1 & 15.36 & 236 \\
\hline Academic-success & 5 & 3 & 5 & 3.87 & 11.49 & 248 \\
\hline Students & 14 & 7 & 8 & 7.48 & 17.35 & 464 \\
\hline Gender-Differences & 5 & 4 & 4 & 4 & 16.73 & 175 \\
\hline Women & 8 & 7 & 7 & 7 & 14.49 & 417 \\
\hline Stem & 8 & 3 & 5 & 3.87 & 12 & 133 \\
\hline Science & 9 & 5 & 8 & 6.32 & 12.65 & 299 \\
\hline STEM-Education & 4 & 1 & 1 & 1 & 1.73 & 3 \\
\hline Achievement & 5 & 3 & 3 & 3 & 4.24 & 38 \\
\hline \multicolumn{7}{|c|}{ Interval 2012} \\
\hline Denomination & Works & Index-h & Index-g & Index-hg & Index- $\mathrm{q}^{2}$ & Citations \\
\hline Science & 22 & 9 & 17 & 12.37 & 19.44 & 632 \\
\hline Perspective & 6 & 4 & 4 & 4 & 6.63 & 59 \\
\hline African-American & 6 & 5 & 5 & 5 & 5.48 & 90 \\
\hline Performance & 17 & 8 & 12 & 9.8 & 17.66 & 404 \\
\hline Knowledge & 6 & 4 & 5 & 4.47 & 10.2 & 101 \\
\hline Curriculum & 3 & 2 & 2 & 2 & 16.97 & 160 \\
\hline \multicolumn{7}{|c|}{ Interval 2013} \\
\hline Denomination & Works & Index-h & Index-g & Index-hg & Index- $\mathrm{q}^{2}$ & Citations \\
\hline Choice & 17 & 9 & 16 & 12 & 13.75 & 459 \\
\hline Gender-Differences & 8 & 4 & 6 & 4.9 & 10.2 & 93 \\
\hline Professional-Development & 7 & 4 & 4 & 4 & 8.94 & 72 \\
\hline Beliefs & 19 & 8 & 13 & 10.2 & 12 & 197 \\
\hline Attitudes & 11 & 6 & 9 & 7.35 & 8.49 & 99 \\
\hline Diversity & 9 & 6 & 7 & 6.48 & 10.39 & 184 \\
\hline Knowledge & 11 & 5 & 10 & 7.07 & 9.22 & 109 \\
\hline STEM & 8 & 5 & 7 & 5.92 & 9.49 & 230 \\
\hline Persistence & 8 & 4 & 4 & 4 & 4.47 & 22 \\
\hline Educational-Choice & 3 & 3 & 3 & 3 & 5.74 & 39 \\
\hline \multicolumn{7}{|c|}{ Interval 2014} \\
\hline Denomination & Works & Index-h & Index-g & Index-hg & Index- $q^{2}$ & Citations \\
\hline Women & 31 & 12 & 18 & 14.7 & 17.32 & 349 \\
\hline Mathematics & 27 & 13 & 21 & 16.52 & 21.02 & 480 \\
\hline Motivation & 12 & 9 & 10 & 9.49 & 11.62 & 177 \\
\hline Perceptions & 17 & 9 & 15 & 11.62 & 12.73 & 231 \\
\hline Race & 8 & 4 & 5 & 4.47 & 12.49 & 125 \\
\hline Teachers & 13 & 6 & 8 & 6.93 & 10.95 & 135 \\
\hline Socialization & 5 & 4 & 4 & 4 & 7.48 & 77 \\
\hline Assessment & 2 & 1 & 1 & 1 & 3.61 & 13 \\
\hline
\end{tabular}


Table 10. Cont.

\begin{tabular}{|c|c|c|c|c|c|c|}
\hline \multicolumn{7}{|c|}{ Interval 2015} \\
\hline Denomination & Works & Index-h & Index-g & Index-hg & Index- $\mathrm{q}^{2}$ & Citations \\
\hline Achievement & 26 & 9 & 15 & 11.62 & 12.73 & 245 \\
\hline Gender & 24 & 10 & 14 & 11.83 & 12.25 & 220 \\
\hline Instruction & 28 & 12 & 18 & 14.7 & 16.25 & 341 \\
\hline Outcomes & 5 & 3 & 3 & 3 & 6.71 & 41 \\
\hline Framework & 9 & 6 & 9 & 7.35 & 10.39 & 109 \\
\hline Perceptions & 10 & 6 & 9 & 7.35 & 8.83 & 85 \\
\hline Higher-Education & 8 & 5 & 7 & 5.92 & 7.07 & 54 \\
\hline Project-Based-Learning & 3 & 2 & 2 & 2 & 10.39 & 57 \\
\hline Diversity & 3 & 1 & 1 & 1 & 4.24 & 18 \\
\hline Environment & 2 & 1 & 1 & 1 & 1 & 1 \\
\hline Classroom & 2 & 1 & 1 & 1 & 1.73 & 3 \\
\hline \multicolumn{7}{|c|}{ Interval 2016} \\
\hline Denomination & Works & Index-h & Index-g & Index-hg & Index- $q^{2}$ & Citations \\
\hline Achievement & 28 & 9 & 13 & 10.82 & 11.22 & 213 \\
\hline Women & 50 & 9 & 12 & 10.39 & 11.62 & 238 \\
\hline Students & 24 & 8 & 13 & 10.2 & 11.66 & 191 \\
\hline Teachers & 11 & 5 & 9 & 6.71 & 5.48 & 92 \\
\hline STEM & 51 & 7 & 10 & 8.37 & 9.17 & 151 \\
\hline STEM-Education & 18 & 7 & 14 & 9.9 & 9.9 & 211 \\
\hline Experience & 12 & 4 & 9 & 6 & 6.63 & 235 \\
\hline Robotics & 5 & 3 & 3 & 3 & 7.14 & 69 \\
\hline \multicolumn{7}{|c|}{ Interval 2017} \\
\hline Denomination & Works & Index-h & Index-g & Index-hg & Index- $^{2}$ & Citations \\
\hline Science & 183 & 11 & 14 & 12.41 & 13.27 & 633 \\
\hline Race & 17 & 5 & 8 & 6.32 & 7.75 & 79 \\
\hline Gender-differences & 22 & 7 & 11 & 8.77 & 10.58 & 137 \\
\hline Engagement & 15 & 5 & 7 & 5.92 & 6.71 & 67 \\
\hline Inquiry & 9 & 2 & 4 & 2.83 & 4.69 & 21 \\
\hline Performance & 21 & 5 & 7 & 5.92 & 6.71 & 79 \\
\hline STEM-Education & 19 & 6 & 9 & 7.35 & 7.75 & 105 \\
\hline Physics & 9 & 3 & 5 & 3.87 & 4.24 & 26 \\
\hline Knowledge & 13 & 4 & 5 & 4.47 & 5.29 & 36 \\
\hline Experience & 6 & 3 & 3 & 3 & 4.24 & 16 \\
\hline \multicolumn{7}{|c|}{ Interval 2018} \\
\hline Denomination & Works & Index-h & Index-g & Index-hg & Index- $\mathrm{q}^{2}$ & Citations \\
\hline Science & 147 & 7 & 9 & 7.94 & 7.94 & 301 \\
\hline Persistence & 27 & 5 & 7 & 5.92 & 6.32 & 74 \\
\hline Race & 25 & 4 & 7 & 5.29 & 6.93 & 63 \\
\hline Instruction & 11 & 4 & 6 & 4.9 & 4.47 & 36 \\
\hline Choice & 27 & 4 & 6 & 4.9 & 4.9 & 64 \\
\hline Impact & 29 & 3 & 4 & 3.46 & 4.24 & 37 \\
\hline Mathematics & 46 & 5 & 6 & 5.48 & 5.94 & 90 \\
\hline Classroom & 10 & 2 & 3 & 2.45 & 3.74 & 15 \\
\hline Sex-differences & 9 & 3 & 4 & 3.46 & 3.46 & 20 \\
\hline Design & 8 & 3 & 4 & 3.46 & 3.87 & 20 \\
\hline Community & 5 & 1 & 1 & 1 & 1.41 & 4 \\
\hline Policy & 4 & 2 & 2 & 2 & 2.83 & 9 \\
\hline \multicolumn{7}{|c|}{ Interval 2019} \\
\hline Denomination & Works & Index-h & Index-g & Index-hg & Index- ${ }^{2}$ & Citations \\
\hline Women & 73 & 3 & 3 & 3 & 3 & 50 \\
\hline Gender-Differences & 34 & 3 & 4 & 3.46 & 3.46 & 32 \\
\hline Persistence & 20 & 2 & 2 & 2 & 2.45 & 15 \\
\hline Mathematics & 96 & 3 & 4 & 3.46 & 3.46 & 60 \\
\hline Professional-development & 17 & 1 & 2 & 1.41 & 1.73 & 5 \\
\hline STEM-Education & 39 & 3 & 3 & 3 & 3 & 26 \\
\hline Motivation & 32 & 3 & 3 & 3 & 3 & 21 \\
\hline
\end{tabular}


Table 10. Cont.

\begin{tabular}{|c|c|c|c|c|c|c|}
\hline \multicolumn{7}{|c|}{ Interval 2019} \\
\hline Denomination & Works & Index-h & Index-g & Index-hg & Index- $q^{2}$ & Citations \\
\hline Higher-Education & 19 & 2 & 2 & 2 & 2 & 7 \\
\hline Computational-Thinking & 9 & 2 & 2 & 2 & 2.83 & 6 \\
\hline Model & 7 & 1 & 1 & 1 & 1.41 & 4 \\
\hline Design & 5 & 2 & 2 & 2 & 2.83 & 6 \\
\hline Intervention & 5 & 2 & 2 & 2 & 2 & 4 \\
\hline Equity & 5 & 2 & 2 & 2 & 2.45 & 5 \\
\hline High-School & 6 & 1 & 1 & 1 & 1.41 & 4 \\
\hline Outcomes & 4 & 1 & 1 & 1 & 1 & 1 \\
\hline Skills & 6 & 1 & 1 & 1 & 1.41 & 3 \\
\hline
\end{tabular}

The diagrams of the established intervals provide information on the relevance of each of the themes, through a process of grouping, bearing in mind Callon's indicators, which analyze the degree of interaction of a network with respect to other networks, from two perspectives: centrality, which measures the strength of external links with other topics, being the measure of the importance of a topic in the development of a certain field of research; and density, which analyzes the internal strength of the network, identifying the internal links between all the key words that are grouped around a specific topic, thus offering the degree of development of the field of study analyzed. The study of all the established diagrams shows how, in 2010, the driving themes were "Stem-cell-research", whose studies focus on "internet", "learn", "qualitative-research", "undergraduate", "misconceptions", "science education", "argumentation" and "evaluation"; "women", whose studies focus on "achievement", "faculty", "ethnicity", "impact", "role models", "inequality", "equity" and "recruitment"; and "knowledge" whose studies focus on "work", "undergraduate education", "science", "skills", "representation", "STEM cells" and "performance". In 2011, it was "faculty" whose studies focus on "research productivity", "men", "identity", "program", "graduate", "career", "mentors" and "job satisfaction"; "gender differences" whose studies focus on "participation", "educational choice", "teachers", "attitudes", "classroom", "question", "curriculum" and "sex differences"; "academic-success" whose studies focus on "color", "qualitative research", "African- American", "underrepresented minorities", persistence", "undergraduate research" and "predominantly white"; and "students" whose studies focus on "gender", "success", "personality", "mathematics", "model", "interest", "environment" and "performance". In 2012, it was "science" whose studies focus on "math", "gender", "self-efficacy", "technology", "choice", "women", "career", and "interests"; and "perspective" whose studies focus on "outcomes", "color", "minority students", "perceptions", "professional development", "recruitment", "diversity" and "faculty". In 2013, it was "gender differences" whose studies focus on "problem solving", "early childhood", "sex differences", "school", "assessment", "Americans", "performance" and "validity"; "attitudes" whose studies focus on "achievement", "school science", "STEM studies", "mathematics", "identity", "perceptions", "STEM careers" and "meta-analysis"; and "choice" whose studies focus on "gender", "academic achievement", "social cognitive", "students", "women", "model", "career" and "science major". In 2014, it was "women" whose studies focus on "gender", "persistence", "stereotype threat", "science", "experiences", "African-American", "career" and "minorities"; "mathematics" whose studies focus on "achievement", "self-efficacy", "success", "beliefs", "gender differences", "high school", "college" and "majors"; and "motivation" whose studies focus on "diversity", "performance", "participation", "technology", "design", "classroom", "math" and "STEM education". In 2015, it was "achievement" whose studies focus on "math", "persistence", "performance", "students", "motivation", "high school" and "career"; "instruction" whose studies focus on "professional development", "inquiry", "integration", "science", “technology", "impact" and "STEM education"; "gender" whose studies focus on "race", "middle school", "online learning", "STEM", "experiences", "choice", "women" and "interests"; "outcomes" whose studies focus on "validity", "mentoring", "quality", "retention", "college", "meta-analysis", "undergraduate research" and "self-efficacy"; "framework" 
whose studies focus on "family", "thinking", "information", "mathematics", "knowledge", "identity", "design" and "university"; and "perceptions" whose studies focus on "benefits", "culture", "success", "teacher", "attitudes", "beliefs", "scientists" and "education". In 2016, it was "women" whose studies focus on "engineering", "gender", "success", "science", "technology", "majors", "career" and "persistence"; and "achievement" whose studies focus on "career choice", "meta-analysis", "physics", "mathematics", "attitudes", "identity", "motivation" and "classroom". In 2017, it was "science" whose studies focus on "gender", "achievement", "mathematics", "STEM", "students", "technology", "school" and "education"; and "gender differences" whose studies focus on "academic achievement", "self-efficacy", "sex differences", "choice", "women", "high school", "career" and "competence". In 2018, it was "race" whose studies focus on "mentoring", "intersectionality", "color", "African-American", "doctoral students", "socialization", "equity", and "faculty"; "choice" whose studies focus on "gender gap", "career", "self-efficacy", "attitudes", "school", "motivation", "model" and "secondary school"; "persistence" whose studies focus on "graduate education", "success", "experiences", "retention", "college", "diversity" and "academic achievement"; and "science" whose studies focus on "math", "gender", "achievement", "STEM", "students", "technology", "beliefs" and "women". In 2019, it was "women" whose studies focus on "minorities", "gender", "girls", "science", "experiences", "choice", "identity" and "majors"; "gender difference" whose studies focus on "sex differences", "stereotype threat", "ability", "math", "meta-analysis", "performance" and "achievement"; "mathematics" whose studies focus on "beliefs", "science education", "mathematics education", "teachers", "STEM", "knowledge", "attitudes" and "technology"; "persistence" whose studies focus on "graduate education", "success", "predictors", "schools", "African-American", "college", "association" and "socialization"; "motivation" whose studies focus on "goals", "fit-indexes", "mixed methods", "students", "innovation", "interests", "adolescents" and "self-efficacy"; and "higher education" whose studies focus on "color", "critical thinking", "strategies", "support", "diversity" and "transition". In this last period, the themes of "equity", "design", "high school" and "mode" should also be taken into account, given that, in the coming years, these may be the new trends in this field of study (Figure 5).

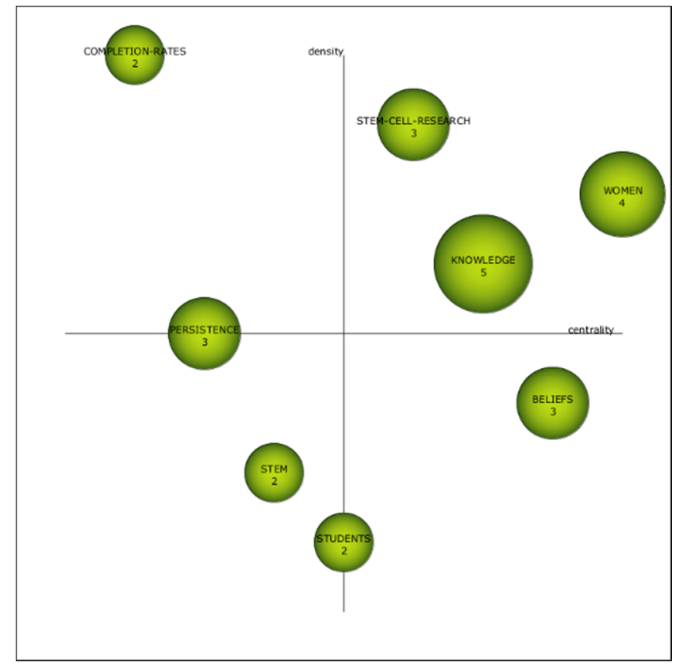

(a)

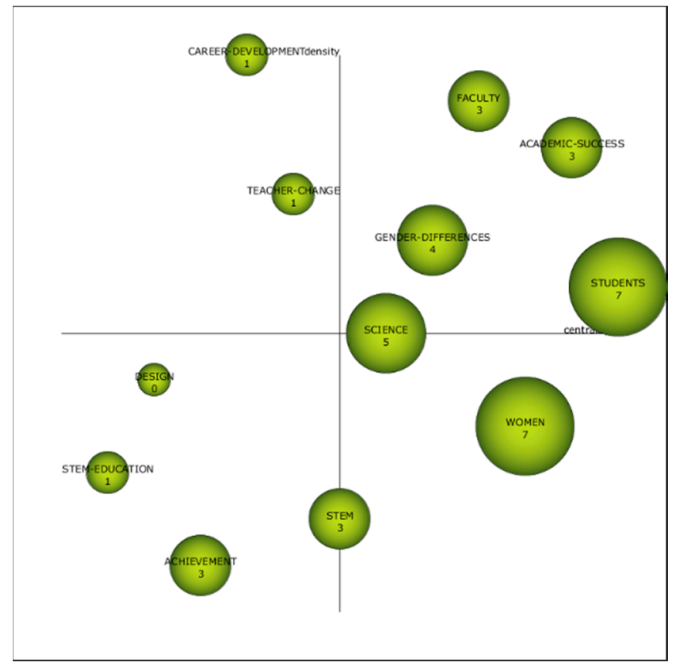

(b)

Figure 5. Cont. 


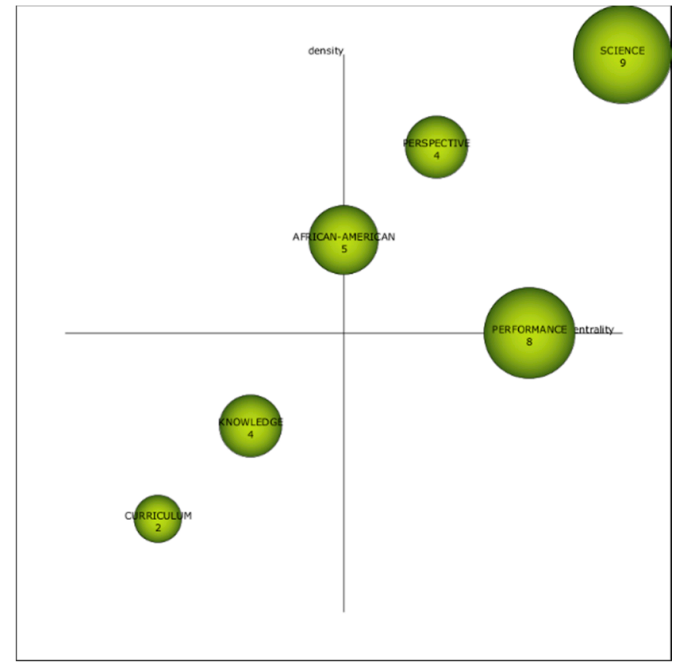

(c)

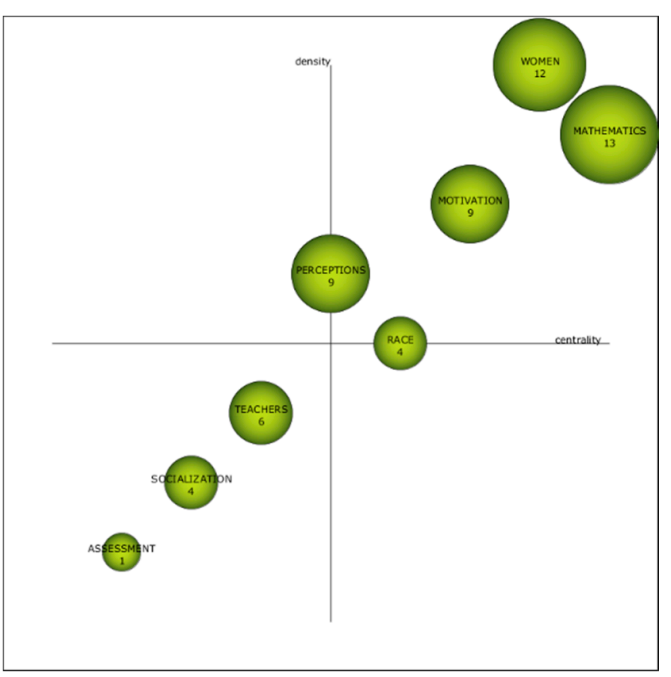

(e)

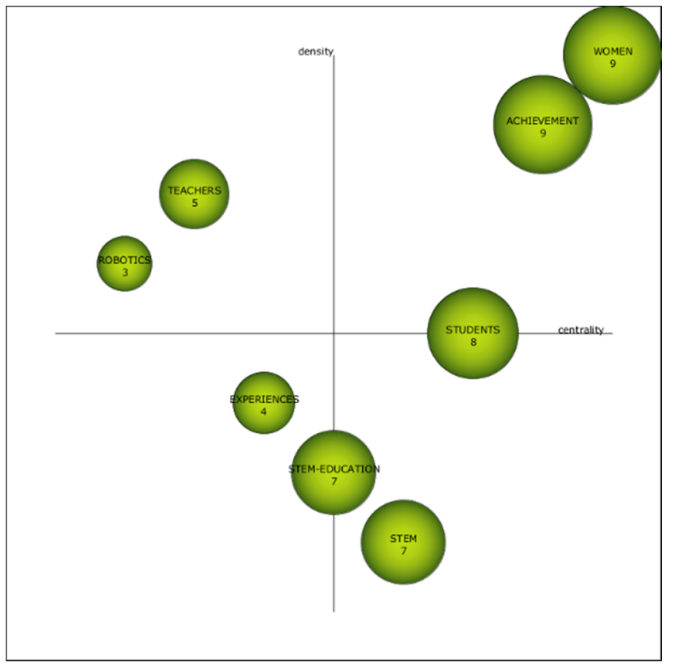

(g)

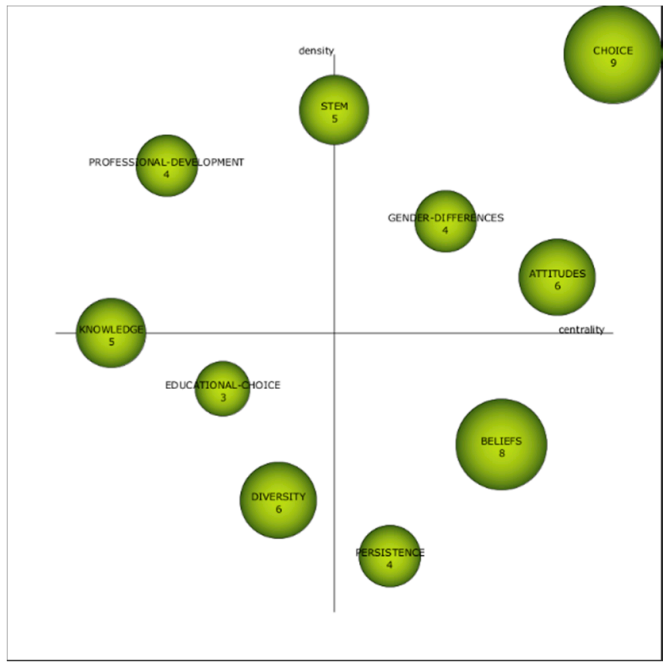

(d)

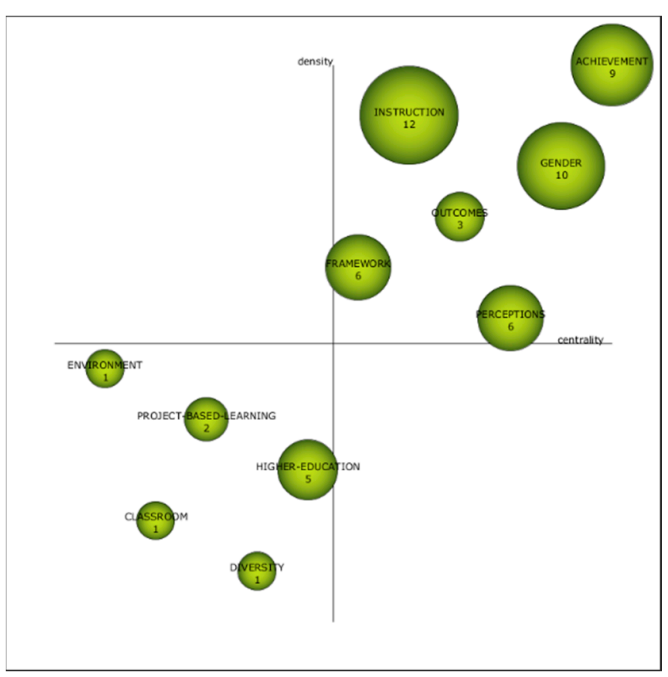

(f)

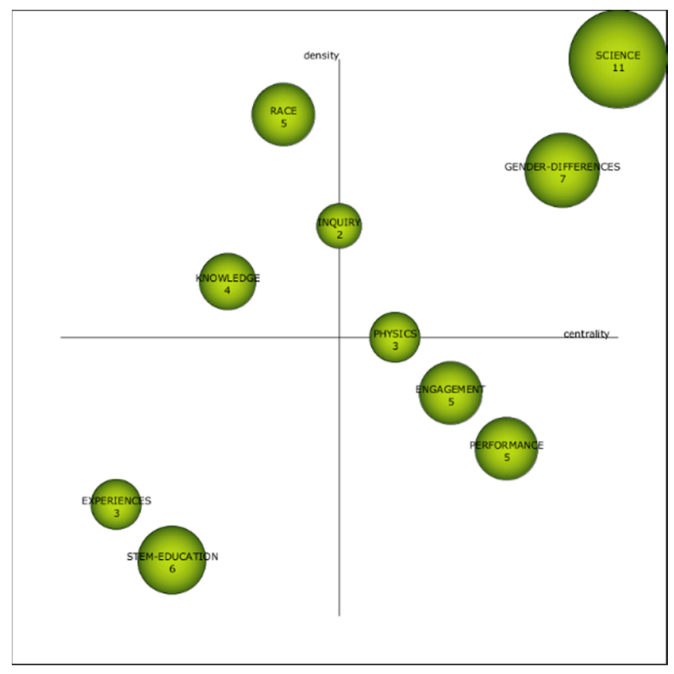

(h)

Figure 5. Cont. 


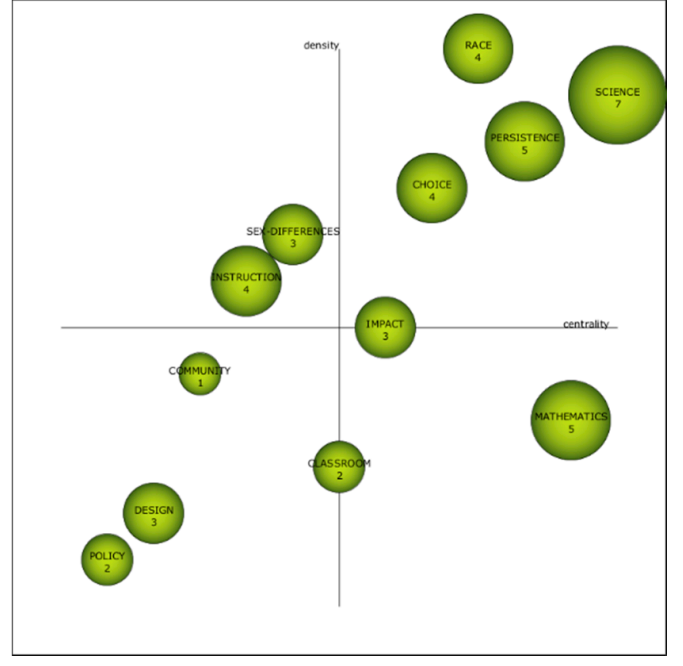

(i)

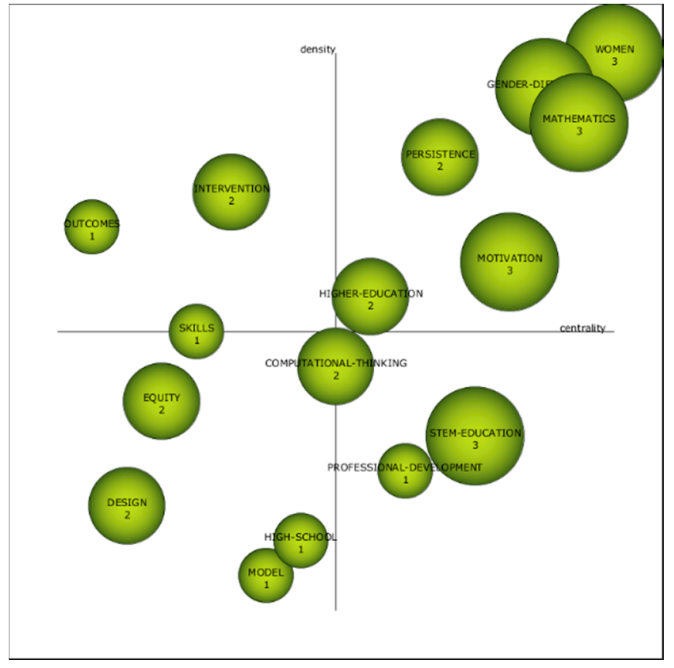

(j)

Figure 5. STEM's strategic diagram by h-index. Note: (a) 2010; (b) 2011; (c) 2012; (d) 2013; (e) 2014; (f) 2015; (g) 2016; (h) 2017; (i) 2018; (j) 2019.

\subsection{Thematic Evolution of the Terms}

The thematic evolution represents the strength of the relationship established between the themes of the various intervals generated, bearing in mind the Jaccard index. The evolution occurs if a theme of a certain interval shares keywords with the previous or contiguous intervals. The more keywords they have in relation to both themes of consecutive intervals, the more solid will be their evolution.

The two types of connections that can occur are represented in the figure with a continuous line or with a discontinuous line. The continuous line is used when the connection between themes is focused on the thematic of the different scientific literature. However, the discontinuous line is used when this connection is based simply in the matching of keywords. The thickness of both types of lines shows the strength of the relationship between the themes.

Bearing in mind the data shown in Figure 6, there is a conceptual gap in the evolution of the study of "STEM" in the educational field, given that there is no one theme that is repeated in all established periods, although it can be seen how the themes "STEM", "women", "science", "gender difference" and "achievement" are repeated several times in different periods. The connections established are mainly thematic, with a greater number of connections in the last period. It is also worth noting that the themes on which the studies are based are cyclical, given that "women" and "science" are important aspects for the scientific community in the years of production. Finally, it can be seen that in the last period, the use of STEM in higher education has become more important.

Another relevant aspect is the variety of research generated over time. This fact is shown by the variety of topics in the different established periods. This fact shows the needs and potentialities that have been produced throughout all of these years regarding the term STEM in education. Although, as we can see, due to the large number of continuous lines shown in the graph, there are common links in research generated in recent times. This shows us a base upon which most research is developed. 


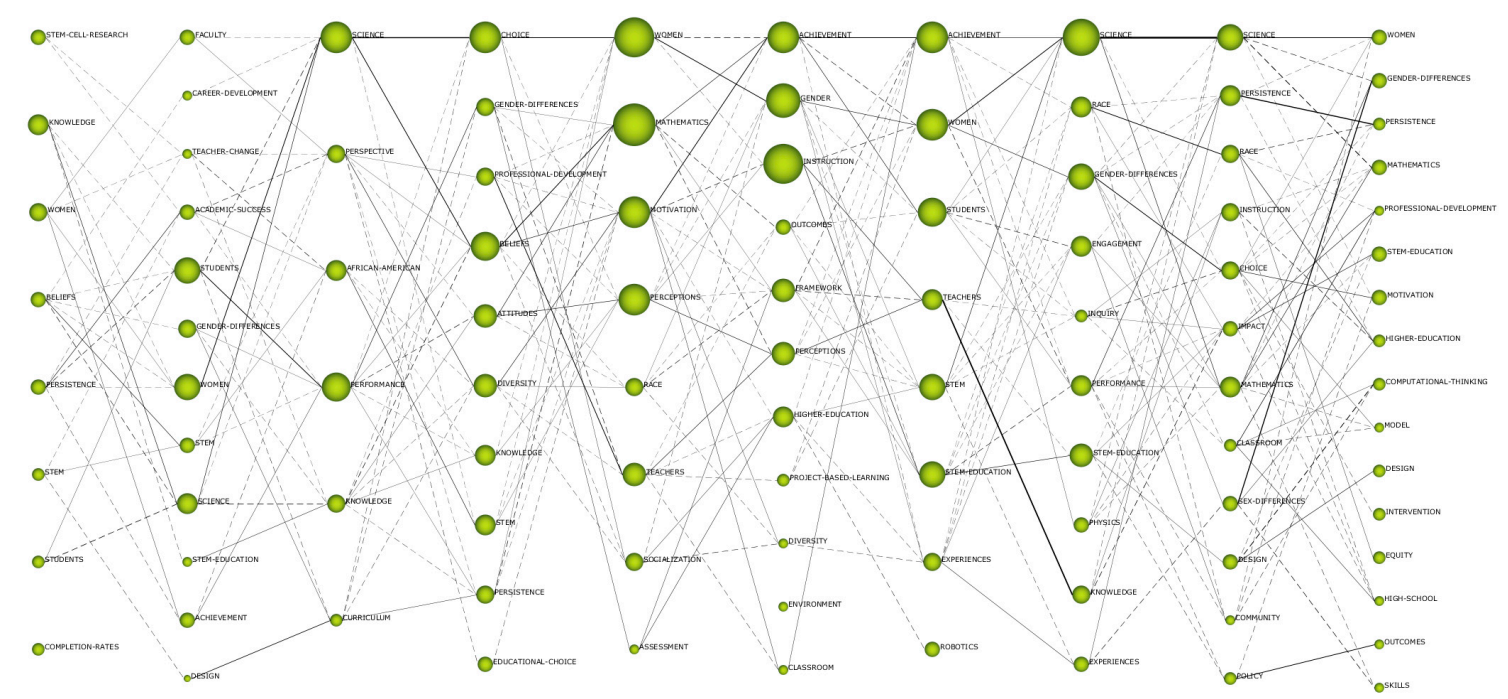

Figure 6. Thematic evolution by h-index.

\section{Discussion and Conclusions}

The term STEM (Science, Technology, Engineering and Mathematics) in the educational field is beginning to have relevance, especially with regard to teaching and learning processes, regardless of the educational stage. The term of STEM education has been introduced in the field of education in recent times. The term takes on different meanings, since for some authors, it is represented as a pedagogical action that prepares students for university engineering courses. Other authors see it as preparation for an engineering profession. For others, it is a component of general education, as it seeks to improve STEM knowledge in the population. The use of STEM in education involves students working in teams, focusing on problem solving, increasing decision-making and creativity, improving critical thinking and self-esteem, acquiring meaningful learning, developing peer interaction, improving self-efficacy, scientific identity and attitude towards mathematics and science, developing active learning, improving reasoning skills, collaboration and self-regulation of learning [21-38].

In this study, we have gone deeper into the dynamic and structural development of the "STEM" concept in the educational field, with the intention of offering relevant information for those researchers who intend to investigate this field. The results obtained allow us to respond to the objectives established previously.

The scientific production of "STEM" in the educational area had its beginnings in 2010, although its evolution has not been uniform, since it has suffered small recessions in the years 2012, 2015 and 2018. The largest production peaks occurred in 2017 and 2019 respectively.

The scientific community mainly uses the English language and, inside it, research articles in contrast to other types of papers, to present their results, although there is a high incidence of communications in the congresses. This fact is very revealing, because it shows and marks the recent development of this subject in this field of study, which is reflected in the sources of origin, where the communications of congresses occupy the first places of production.

The main institution in research on "STEM" in education is Purdue University, with the authors T.J. Moore and C.C. Johnson as the most prolific ones in this area, although not the most cited, given that Grover and Pea (2013) are benchmarks, with a high rate of citation. The United States, along with England and Australia, are the countries with the greatest interest in the subject.

A key moment in the evolution of the subject is in 2015, given that before that date, the field of study was not yet established, there being a great diversity of key words used by the scientific community when establishing the main lines of research. However, after that moment, the thematic begins to settle. It is remarkable how the topics "science" and "women" are the ones that have had the greatest relevance on the part of the scientific community, which have marked the main trends 
in research in the use of "STEM" in the educational field. This shows how there are differences at the level of gender in its use in teaching and learning processes. This is an aspect than can generate controversy, given that, in the educational field, all discrepancies based on gender, race, culture or sexual identity must be avoided, as marked by [52-55].

In the background, topics such as "motivation", "higher education" and "mathematics" are emerging as relevant and of great importance in the scientific literature, which makes us see new pedagogical actions, oriented to motivation, in subjects such as mathematics, and in educational stages such as higher education.

It can be concluded that the term STEM has a greater and growing incidence within the educational community, due to the boom in scientific production generated in recent years, especially in the United States, England and Australia, with articles in English being the medium used to present results by researchers. The main themes that focus the attention of researchers on the term STEM in the educational field are "science" and "women", although new lines of research are beginning to appear, aimed at "motivation", "higher education" and "mathematics". In addition, sustainability is not among the most research-oriented aspects of research.

This study is important for educators, policy makers and STEM professionals because it offers a concrete and specific vision of the current situation of the term STEM in education, showing the most relevant aspects for the scientific community at this time. It also offers a concrete view of the evolution of this terminology over the last few years, thus showing the most relevant needs for the scientific community. Furthermore, it offers possible future lines of research in the coming years. With all this, the educational community can learn about the main virtues and difficulties associated with the term STEM in education.

The prospective of this research is to offer the scientific community the trends in the study of STEM in the educational field, as well as to show the competent educational administrations the needs to apply educational programs where the use of educational STEM is promoted among men and women.

The limitations of this research focus on the purification of the data presented in WoS, due to the fact that the database, on certain occasions, collects repeated documents or documents that are not within the established search field. Another aspect to bear in mind among the limitations are the parameters marked in this study, which have been established according to the criteria of the researchers. These were implemented trying to present results in accordance with the size and relevance; so, that is the reason why the data presented here must be analyzed with caution, due to the fact that the data are not always available. As future lines of research, we plan to carry out studies that analyze the impact of the practical application of the STEM teaching method with respect to the expository method.

Author Contributions: Conceptualization, M.R.N.-P, P.D.-T. and C.R.-J.; methodology, C.R.-J. and P.D.-T.; software, A.-J.M.-G.; formal analysis, A.-J.M.-G.; investigation, M.R.N.-P., P.D.-T., C.R.-J., A.-J.M.-G. and F.-J.H.-L.; data curation, C.R.-J. and A.-J.M.-G.; writing-original draft preparation, M.R.N.-P., C.R.-J., A.-J.M.-G., P.D.-T. and F.-J.H.-L.; writing - review and editing, M.R.N.-P., C.R.-J., A.-J.M.-G., P.D.-T. and F.-J.H.-L.; visualization, P.D.-T.; supervision, F.-J.H.-L. All authors have read and agreed to the published version of the manuscript.

Funding: This research received no external funding.

Acknowledgments: We acknowledge the researchers of the research group AREA (HUM-672), which belongs to the Ministry of Education and Science of the Junta de Andalucía and is registered in the Department of Didactics and School Organization of the Faculty of Education Sciences of the University of Granada.

Conflicts of Interest: The authors declare no conflict of interest.

\section{References}

1. Ifinedo, E.; Rikala, J.; Hamalainen, T. Factors affecting Nigerian teacher educators' technology integration: Considering characteristics, knowledge constructs, ICT practices and beliefs. Comput. Educ. 2020, 146, 103760. [CrossRef] 
2. Gemiya, A.G. Factors Affecting the Use of ICT Services in Ethiopia: The Case of Illubabor Zone-Oromia Regional State. Int. J. Inf. Commun. Technol. Educ. 2020, 16, 50-60. [CrossRef]

3. Molodozhnikova, N.M.; Biryukova, N.V.; Galustyan, O.V.; Lazareva, J.B.; Stroiteleva, N.N. Formation of Professional Orientation of High School Students to Medical Profession by Using ICT Tools. Int. J. Emerg. Technol. Learn. 2020, 15, 231-239. [CrossRef]

4. Carrión, E. The use of ICT in educational inclusion: Bullying, components and gender difference. EDMETIC 2020, 9, 126-148. [CrossRef]

5. Moreno-Guerrero, A.J.; López, J.; Pozo, S.; Fuentes, A. Influence of the context on the use of ICT devices in Basic Vocational Training. EDMETIC 2020, 9, 149-169. [CrossRef]

6. Sharma, E. Developing ICT adoption model based on the perceived awareness and perceived usefulness of technology among telecom users. Int. J. Technol. Enhanc. Learn. 2020, 12, 99-114. [CrossRef]

7. Chen, M.; Zhou, C.; Meng, C.Y.; Wu, D. How to promote Chinese primary and secondary school teachers to use ICT to develop high-quality teaching activities. Educ. Technol. Res. Dev. 2019, 67, 1593-1611. [CrossRef]

8. Senkbeil, M.; Ihme, J.M.; Schöeber, C. Are first-semester and advanced university students ready for life and work in the digital world? Results of a standard setting method to describe ICT-related proficiency levels. Z. Fur Erzieh. 2019, 22, 1359-1384. [CrossRef]

9. Enakrire, R.T. ICT-related training and support Programmes for information professionals. Educ. Inf. Technol. 2019, 24, 3269-3287. [CrossRef]

10. Moreno-Guerrero, A.J.; Romero-Rodríguez, J.M.; López-Belmonte, J.; Alonso-García, S. Flipped Learning Approach as Educational Innovation in Water Literacy. Water 2020, 12, 574. [CrossRef]

11. Moreno-Guerrero, A.J.; Rondón, M.; Martínez, N.; Rodríguez-García, A.M. Collaborative Learning Based on Harry Potter for Learning Geometric Figures in the Subject of Mathematics. Mathematics 2020, 8, 369. [CrossRef]

12. Cabero, J.; Barroso, J. Los escenarios tecnológicos en Realidad Aumentada (RA): Posibilidades educativas en estudios universitarios. Aula Abierta 2018, 47, 327-336. [CrossRef]

13. Verdin, D.; Godwin, A.; Klotz, L. Exploring the Sustainability-Related Career Outcome Expectations of Community College Students Interested in Science and Engineering Careers. Community Coll. J. Res. Pract. 2020, 44, 83-98. [CrossRef]

14. Saw, G. The Impact of Inclusive STEM High Schools on Student Outcomes: A Statewide Longitudinal Evaluation of Texas STEM Academies. Int. J. Sci. Math. Educ. 2019, 17, 1445-1457. [CrossRef]

15. Sylverster, P.; Myran, S. "Minding the Gaps": Career Navigators as an Illustration for Supporting Student Growth and Learning. Community Coll. J. Res. Pract. 2020, 44, 147-161. [CrossRef]

16. Ramey, K.E.; Stevens, R. Interest development and learning in choice-based, in-school, making activities: The case of a 3D printer. Learn. Cult. Soc. Interact. 2019, 23, 1-13. [CrossRef]

17. Campbell, A.; Craig, T.; Collier-Reed, B. A framework for using learning theories to inform 'growth mindset' activities. Int. J. Math. Educ. Sci. Technol. 2020, 51, 26-43. [CrossRef]

18. Peters-Burton, E.E.; House, A.; Peters, V.; Remold, J. Understanding STEM-focused elementary schools: Case study of Walter Bracken STEAM Academy. Sch. Sci. Math. 2019, 119, 446-456. [CrossRef]

19. Siverling, E.A.; Suazo-Flores, E.; Mathis, C.A.; Moore, T.J. Students' use of STEM content in design justifications during engineering design-based STEM integration. Sch. Sci. Math. 2019, 119, 457-474. [CrossRef]

20. Howard, M.; Kern, A. The role of story and place in Indigenous science education: Bigfoot in a youth-designed ecological restoration plan. Cult. Stud. Sci. Educ. 2019, 14, 915-935. [CrossRef]

21. Williams, P.J. STEM education: Proceed with caution. Des. Technol. Educ. Int. J. 2011, 16, 27-35.

22. Gil-Domenech, D.; Berbegal-Mirabent, J. Stimulating students' engagement in mathematics courses in non-STEM academic programmes: A game-based learning. Innov. Educ. Teach. Int. 2019, 56, 57-65. [CrossRef]

23. Saienki, N.; Olizko, Y.; Arshad, M. Development of Tasks with Art Elements for Teaching Engineers in English for Specific Purposes Classroom. Int. J. Emerg. Technol. Learn. 2019, 14, 4-16. [CrossRef]

24. Mwenda, A.B.; Sullivan, M.; Grand, A. How do Australian universities market STEM courses in YouTube videos? J. Mark. High. Educ. 2019, 29, 191-208. [CrossRef]

25. Ferrada, C.; Díaz-Levicoy, D.; Salgado-Orellana, N.; Parraguez, R. Proposals of mathematical activities with a Bee-bot child robot based on STEM education. Edma 0-6 Educ. Mat. Infanc. 2019, 8, 33-43. 
26. Sigal, M.; Jacobs, S. Preparing for University: An Applied Analysis on the Efficacy of $4 \mathrm{U}$ and University Level Preparatory STEM Courses. Can. J. Scholarsh. Teach. Learn. 2019, 10, 1-23. [CrossRef]

27. Davila-Guzmán, N.E.; Tiempos-Flores, N.; Maya-Trevino, M.L.; Sánchez-Vázquez, A.I.; Cerino-Cordova, F.D. Educational Content Development to Enhance STEM Learning. Int. J. Emerg. Technol. Learn. 2019, 14, 235-242. [CrossRef]

28. Pyraz, G.T.; Kumpete, E.G. An Example of STEM Education in Turkey and Distance Education for Sustainable STEM Learning. J. Qual. Res. Educ. 2019, 7, 1345-1364. [CrossRef]

29. González, E.O.; Estévez, E.H.; Del Cid, C.J. Effects of public policies on the preferences and orientation of the activities carried out by academics in STEM areas of IES de Mexico. Educ. Policy Anal. Arch. 2019, 27, 19. [CrossRef]

30. Wu, T.; Albion, P. Investigating Remote Access Laboratories for Increasing Pre-service Teachers' STEM Capabilities. Educ. Technol. Soc. 2019, 22, 82-93.

31. Musabirov, I.; Pozdniakov, S.; Tenisheva, K. Predictors of Academic Achievement in Blended Learning: The Case of Data Science Minor. Int. J. Emerg. Technol. Learn. 2019, 14, 64-74. [CrossRef]

32. Searle, K.A.; Tofel-Grehl, C.; Breitenstein, J. Equitable Engagement in STEM: Using E-textiles to Challenge the Positioning of Non-dominant Girls in School Science. Int. J. Multicult. Educ. 2019, 21, 42-61. [CrossRef]

33. Schlegel, R.J.; Chu, S.L.; Chen, K.; Deuermeyer, E.; Christy, A.G.; Quek, F. Making in the classroom: Longitudinal evidence of increases in self-efficacy and STEM possible selves over time. Comput. Educ. 2019, 142, 103637. [CrossRef]

34. Wang, X.L.; Lee, S.Y. Investigating the Psychometric Properties of a New Survey Instrument Measuring Factors Related to Upward Transfer in STEM Fields. Rev. High. Educ. 2019, 42, 339-384. [CrossRef]

35. Miner-Romanoff, K.; Sweetland, Y.; Yang, Y.; Fennema, B. Assessment of Professional Development and Research-Based Instructional Strategies for Instructors of Online Undergraduate STEM Courses. Int. J. Online Pedagog. Course Des. 2019, 9, 51-61. [CrossRef]

36. Van den Hurk, A.; Meelissen, M.; Van Langen, A. Interventions in education to prevent STEM pipeline leakage. Int. J. Sci. Educ. 2019, 41, 150-164. [CrossRef]

37. Ikuma, L.H.; Steele, A.; Dann, S.; Adio, O.; Waggenspack, W.N. Large-scale student programs increase persistence in STEM fields in a public university setting. J. Eng. Educ. 2019, 108, 57-81. [CrossRef]

38. Schachter, R.E.; Strang, T.M.; Piasta, S.B. Teachers' experiences with a state-mandated kindergarten readiness assessment. Early Years 2019, 39, 80-96. [CrossRef]

39. Emery, N.; Maher, J.M.; Ebert-May, D. Studying Professional Development as Part of the Complex Ecosystem of STEM Higher Education. Innov. High. Educ. 2019, 44, 469-479. [CrossRef]

40. Nesmith, S.M.; Cooper, S. Engineering process as a focus: STEM professional development with elementary STEM-focused professional development schools. Sch. Sci. Math. 2019, 119, 487-498. [CrossRef]

41. Zheng, J.; Xing, W.L.; Zhu, G.X.; Chen, G.H.; Zhao, H.L.; Xie, C. Profiling self-regulation behaviors in STEM learning of engineering design. Comput. Educ. 2020, 143, 103669. [CrossRef]

42. Lee, S.W.; Mamerow, G. Understanding the role cumulative exposure to highly qualified science teachers plays in students' educational pathways. J. Res. Sci. Teach. 2019, 56, 1362-1383. [CrossRef]

43. Morris, B.J.; Owens, W.; Ellenbogen, K.; Erduran, S.; Dunlosky, J. Measuring informal STEM learning supports across contexts and time. Int. J. Stem Educ. 2019, 6, 40. [CrossRef]

44. Chehlarova, T. Op Art in mathematics education or counting of quadrilaterals. Pedagogika 2019, 31, 1-9.

45. Hawkins, I.; Ratan, R.; Blair, D.; Fordham, J. The Effects of Gender Role Stereotypes in Digital Learning Games on Motivation for STEM Achievement. J. Sci. Educ. Technol. 2019, 28, 628-637. [CrossRef]

46. Eilam, B.; Alon, U. Children's Object Structure Perspective-Taking: Training and Assessment. Int. J. Sci. Math. Educ. 2019, 17, 1541-1562. [CrossRef]

47. Horvitz, B.S.; García, L.R.; Mitchell, R.G.; Calhoun, C.D. An Examination of Instructional Approaches in Online Technical Education in Community Colleges. Online Learn. 2019, 23, 237-252. [CrossRef]

48. Bers, M.U. Coding as another language: A pedagogical approach for teaching computer science in early childhood. J. Comput. Educ. 2019, 6, 499-528. [CrossRef]

49. Moreira, R.G.; Butler-Purry, K.; Carter-Sowell, A.; Walton, S.; Juranek, I.V.; Challoo, L.; Regisford, G.; Coffin, R.; Spaulding, A. Innovative Professional Development and Community Building Activity Program Improves STEM URM Graduate Student Experiences. Int. J. STEM Educ. 2019, 6, 34. [CrossRef] 
50. Ergun, A.; Kiyici, G. The effect of design based science education applications of science teacher candidates on their perceptions of engineering education and engineer. Pegem J. Educ. Instr. 2019, 9, 1031-1061. [CrossRef]

51. Klippel, A.; Zhao, J.Y.; Jackson, K.L.; La Femina, P.; Stubbs, C.; Wetzel, R.; Blair, J.; Wallgrun, J.O.; Oprean, D. Transforming Earth Science Education Through Immersive Experiences: Delivering on a Long Held Promise. J. Educ. Comput. Res. 2019, 57, 1745-1771. [CrossRef]

52. Monsalvete, L.; Méndez, Y.; Villalonga, Y.S. Science and Technology: Gender gaps in Europe and Latin America. Atenas 2020, 1, 135-150.

53. Wade-Jaimes, K.; Cohen, J.D.; Calandra, B. Mapping the evolution of an after-school STEM club for African American girls using activity theory. Cult. Stud. Sci. Educ. 2019, 14, 981-1010. [CrossRef]

54. Tajmel, T. Pathways, intersections and leaky pipelines: The cognitive function of metaphors for research on STEM careers. Cult. Stud. Sci. Educ. 2019, 14, 1105-1113. [CrossRef]

55. Todd, B.; Zvoch, K. Exploring Girls' Science Affinities Through an Informal Science Education Program. Res. Sci. Educ. 2019, 49, 1647-1676. [CrossRef]

56. García-Peñalvo, F.J.; Bello, A.; Domínguez, A.; Romero, R.M. Gender Balance Actions, Policies and Strategies for STEM: Results from a World Cafe Conversation. Educ. Knowl. Soc. 2019, 20, 31-31-31-15.31. [CrossRef]

57. Tissenbaum, M. I see what you did there! Divergent collaboration and learner transitions from unproductive to productive states in open-ended inquiry. Comput. Educ. 2020, 145, 103739. [CrossRef]

58. Howard, M.A.; Kern, A.L. Conceptions of wayfinding: Decolonizing science education in pursuit of Native American success. Cult. Stud. Sci. Educ. 2019, 14, 1135-1148. [CrossRef]

59. Hite, R.; Jones, M.G.; Andre, T.; Childers, G.; Corin, E. Female and minority experiences in an astronomy-based science hobby. Cult. Stud. Sci. Educ. 2019, 14, 937-962. [CrossRef]

60. Lin, T.J.; Lin, T.C.; Potvin, P.; Tsai, C.C. Research trends in science education from 2013 to 2017: A systematic content analysis of publications in selected journals. Int. J. Sci. Educ. 2019, 41, 367-387. [CrossRef]

61. Gutiérrez-Salcedo, M.; Martínez, M.A.; Moral-Muñoz, J.A.; Herrera-Viedma, E.; Cobo, M.J. Some bibliometric procedures for analyzing and evaluating research fields. Appl. Intell. 2017, 48, 1275-1297. [CrossRef]

62. Moreno, A.J. Estudio bibliométrico de la Producción Científica sobre la Inspección Educativa. REICE Revis. Iberoam. Sobre Calid. Efica. Camb. Educ. 2019, 17, 23-40. [CrossRef]

63. Campos, M.; Ramos, M.; Moreno-Guerrero, A.J. Realidad virtual y motivación en el contexto educativo: Estudio bibliométrico de los últimos veinte años de Scopus. Alteridad 2020, 15, 47-60. [CrossRef]

64. Moreno-Guerrero, A.J.; Romero-Rodríguez, J.M.; Ramos, M.; Alonso, S. Bibliometric Analysis on Educational Inspection in the Web of Science Database. REICE Revis. Iberoam. Sobre Calid. Efica. Camb. Educ. 2020, 18, 83-103. [CrossRef]

65. Moreno-Guerrero, A.J. Estudio bibliométrico de la producción científica en Web of Science: Formación Profesional y blended learning. Píxel-Bit. Revis. Medios Educ. 2019, 149-168. [CrossRef]

66. Rodríguez-García, A.M.; Fernández, M.A.; Moreno-Guerrero, A.J. Evolución científica de lenguas en el contexto universitario (1900-2019). Texto Livre Ling. Tecnol. 2019, 12, 16-36. [CrossRef]

67. López, J.; Moreno-Guerrero, A.J.; López, J.A.; Pozo, S. Analysis of the Productive, Structural, and Dynamic Development of Augmented Reality in Higher Education Research on the Web of Science. Appl. Sci. 2019, 9, 5306. [CrossRef]

68. Hirsch, J.E. An index to quantify an individual's scientific research output. Proc. Natl. Acad. Sci. USA 2005, 102, 16569-16572. [CrossRef]

69. Cobo, M.J.; López, A.G.; Herrera, E.; Herrera, F. Science mapping software tools: Review, analysis, and cooperative study among tools. J. Am. Soc. Inf. Sci. Technol. 2011, 62, 1382-1402. [CrossRef]

70. Rodríguez-García, A.M.; López, J.; Agreda, M.; Moreno-Guerrero, A.J. Productive, Structural and Dynamic Study of the Concept of Sustainability in the Educational Field. Sustainability 2019, 11, 5613. [CrossRef]

71. Rodríguez-García, A.M.; Moreno-Guerrero, A.J.; López-Belmonte, J. Nomophobia: An Individual's Growing Fear of Being without a Smartphone-A Systematic Literature Review. Int. J. Environ. Res. Public Health 2020, 17, 580. [CrossRef] [PubMed]

72. Martínez, M.A.; Cobo, M.J.; Herrera, M.; Herrera, E. Analyzing the scientific evolution of social work using science mapping. Res. Soc. Work Pract. 2015, 25, 257-277. [CrossRef]

73. Cobo, M.J.; López-Herrera, A.G.; Herrera-Viedma, E.; Herrera, F. SciMAT: A new Science Mapping Analysis Software Tool. J. Am. Soc. Inf. Sci. Technol. 2012, 63, 1609-1630. [CrossRef] 
74. Montero-Díaz, J.; Cobo, M.J.; Gutiérrez-Salcedo, M.; Segado-Boj, F.; Herrera-Viedma, E. A science mapping analysis of 'Communication' WoS subject category (1980-2013). Comunicar 2018, 81-91. [CrossRef]

75. Grover, S.; Pea, R. Computational Thinking in K-12: A Review of the State of the Field. Educ. Res. 2013, 42, 38-43. [CrossRef]

76. Henderson, C.; Beach, A.; Finkelstein, N. Facilitating Change in Undergraduate STEM Instructional Practices: An Analytic Review of the Literature. J. Res. Sci. Teach. 2011, 48, 952-984. [CrossRef]

77. Maltese, A.V.; Tai, R.H. Pipeline Persistence: Examining the Association of Educational Experiences With Earned Degrees in STEM Among US Students. Sci. Educ. 2011, 95, 877-907. [CrossRef]

78. Boyle, E.A.; Hainey, T.; Connolly, T.M.; Gray, G.; Earp, J.; Ott, M.; Lim, T.; Ninaus, M.; Ribeiro, C.; Pereira, J. An update to the systematic literature review of empirical evidence of the impacts and outcomes of computer games and serious games. Comput. Educ. 2016, 94, 178-192. [CrossRef]

79. Jan, R.; Ahmad, R. H-Index and Its Variants: Which Variant Fairly Assess Author's Achievements. J. Inf. Technol. Res. 2020, 13, 68-76. [CrossRef]

80. Mendes, J.V.; Oliveira, G.R.; De Souza, L.M. The G-Index: A sustainability reporting assessment tool. Int. J. Sustain. Dev. World Ecol. 2019, 26, 428-438. [CrossRef]

81. Alonso, S.; Cabrerizo, F.J.; Herrera-Viedma, E.; Herrera, F. Hg-index: A new index to characterize the scientific output of researchers based on the h- and g-indices. Scientometrics 2010, 82, 391-400. [CrossRef]

82. Varotsos, P.A.; Sarlis, N.V.; Skordas, E.S. Tsallis Entropy Index q and the Complexity Measure of Seismicity in Natural Time under Time Reversal before the M9 Tohoku Earthquake in 2011. Entropy 2020, $20,757$. [CrossRef]

(C) 2020 by the authors. Licensee MDPI, Basel, Switzerland. This article is an open access article distributed under the terms and conditions of the Creative Commons Attribution (CC BY) license (http://creativecommons.org/licenses/by/4.0/). 